\title{
REVIEW
}

\section{Application of microreactors in medicine and biomedicine}

\author{
Anita Šalić ${ }^{1}$, Ana Tušek ${ }^{2}$, Bruno Zelić ${ }^{1}$ \\ ${ }^{1}$ University of Zagreb, Faculty of Chemical Engineering and Technology, Zagreb, Croatia \\ ${ }^{2}$ University of Zagreb, Faculty of Food Technology and Biotechnology, Zagreb, Croatia
}

Received $17^{\text {th }}$ October 2011.

Revised $3^{\text {rd }}$ January 2012.

Published online $31^{\text {st }}$ January 2012.

\begin{abstract}
Summary
Microreactor technology is an interdisciplinary field that combines science and engineering. This new concept in production, analysis and research is finding increasing application in many different fields. Benefits of this new technology pose a vital influence on chemical industry, biotechnology, the pharmaceutical industry and medicine, life science, clinical and environmental diagnostic. In the last few years, together with microplant development, a great part of research investigation is focused on integrated micro-systems, the so called micro-total-analysis-systems ( $\mu$-TAS) or lab-on-chip (LOC). They are devices that perform sampling, sample preparation, detection and date processing in integrated model. Cell sorting, cell lysis, single cell analysis and non-destructive single cell experiments on just one microreactor, makes the LOC platform possible. Clinical diagnostic devices are also leaning towards completely integrated, multiple sophisticated biochemical analyses (PCR amplification, cell lysis, separation and detection) all on a single platform and in real time. Special attention is also paid to the usage of microdevices in tissue. Tissue engineering is one of the most promising fields that can lead to in vitro tissue and organ reconstruction ready for implantation and microdevices can be used to promote the migration, proliferation and the differentiation of cells in controlled situations.
\end{abstract}

Key words: microreactors; microfluidics; medicine; biomedicine; micro-total-analysis-system; lab-on-chip

\section{INTRODUCTION}

In the past few years, microreactor technology has demonstrated numerous advantages in different fields of application. It is presented as a novel and break trough technology on which the new concept of production and research will be built upon. The chemical industry, biotechnology, pharmaceutical

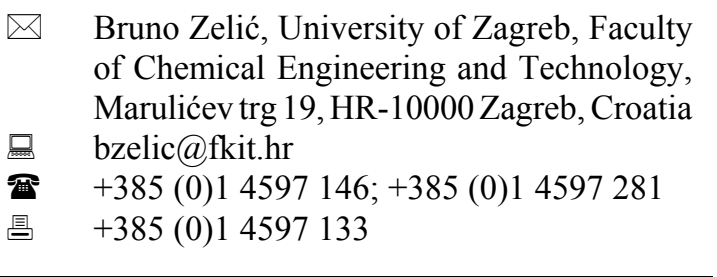

(C) Journal of Applied Biomedicine industry and medicine, life science, clinical and environmental diagnostic are just some of the small fields where this new concept in production, analysis and research could find its place of application. By decreasing the equipment size by several magnitude levels, substantial economical benefits, improvement of intrinsic safety, and a reduction of environmental impact can be achieved (Rebrov et al. 2003). In biotechnology and biochemical processing, the need to manipulate fluids moving in a narrow channel has stimulated several new research areas such as the development of new microfabrication methods for fluidic systems, the study of the fundamental behaviour of fluids etc. (Chován and Guttman 2002). Microreactors can be used both as research instruments in a laboratory scale to enhance the development of new catalysts and processes and for 
the determination of reaction kinetics as well as real production units in a large scale (Hernandez Carucci et al. 2009). From the medical and biomedicine point of view, clinical diagnostic devices using microreactor concepts are leaning towards completely integrated, multiple sophisticated biochemical analyses (PCR amplification, cell lysis, separation and detection) all on a single platform and in real time. The ability to miniaturize entire biomedical systems has the potential to reduce the cost of health-care management. There is also special attention paid to the usage of microdevices in tissue engineering and microengineering development. In this manuscript an intensive overview of the recent developments in the field of microfluidic technology in medicine and biomedicine will be given.

\section{MICROREACTORS IN GENERAL}

Microreactors are defined as miniaturized reaction systems fabricated by using, at least partially, methods of microtechnology and precision engineering (Ehrfeld et al. 2005). The term "microreactor" is the name that is generally used to describe a great number of devices that have small dimensions. Other names that are rarely used are nano-, mili- and mini-reactors. Most of the currently used structured microreaction devices take advantage of microfluidics and nanofluidics, which enables the use of micro and nanolitre volumes that ensure high efficiency as well as repeatability of biocatalytic processes (Urban et al. 2006).

\section{Structure}

Microreactors, in their simplest form, consist of a network of microchannels (Fig. 1a), in the range of $10 \mu \mathrm{m}$ to $500 \mu \mathrm{m}$ etched in a solid substrate. They may be fabricated from different materials including glass, silicon, quartz, metals and polymers such as polydimethylsiloxene (PDMS). Optimal material selection depends on chemical compatibility with solvents and reagents, costs and detection methods used in price control. The most commonly used material is glass since it is chemically inert and transparent which allows the visual inspection of microchannels (McCreedy 2000). Metal devices are often used in fast exothermic, heterogeneously catalyzed reactions and in different separation processes. Different fabrication techniques are also included in microchannel production. Photolithography, hot embossing, powder blasting, injection moulding, ultrasonic technologies and laser microformation are just some of them. It is also possible to combine different techniques. A combination of lithography, electroplating and modelling, called LIGA, was successfully used for the production of microreactors. Selection of a fabrication technique has a great impact on the flow in a microchannel where a rough surface can have a negative effect on fluid movement (i.e. on flow stability) so it is necessary to select an appropriate production technique. Microchannels or microchannel networks, if the device consists of several connected channels, are connected to series of reservoirs containing reagents by fused connectors. Reagents can be brought together on a specific sequence, mixed and allowed to react for a specific time in a controlled conditions using (most commonly) electrokinetic and/or hydrodynamic pumping. Combination of microchannels and supporting base material form a chip (Fig. 1b). A combination of a chip, supporting base material and connecting fluid lines form a unit (Fig. 1c). By a combination of other microdevices (micro mixers, micro heat exchangers, micro separator, micro absorbers etc.) and different element configurations, more complex devices, like some mentioned in this paper, are being developed. Should the throughput be increased, units with the same parameters and characteristics are being combined into a series or in parallel (see "numbering-up").

\section{Basic characteristics and advantages}

Microreactors exhibit numerous practical and performance advantages when compared to traditional, equivalent macroreactors. The small dimensions of microreactors allow usage of minimal amounts of reagent under precisely controlled conditions and make it possible to rapidly screen reaction conditions and improve the overall safety of the process (Gerey et al. 2006). Beside that, excellent mass and heat transfer, shorter residence time, a smaller amount of reagents, lightweight and compact system design, catalyst and waste products comparing to equivalent macroscale reactors, laminar flow, effective mixing, better process control and small energy consumption are just some of the microsystem advantages (Ehrfeld et al. 2005). Furthermore, they could be easily coupled with numerous detection techniques together with the pretreatment of the samples on the one single chip. But one of the main motivations for the use of microreactor technology is the gain in the yield and safety.

As mentioned, given the small dimensions, the flow regime is typically laminar. This type of flow favours the control and modelling of the reaction and provides high surface to volume ratio and interface areas, which is very important especially for multiphase systems. Flow in the microreactor can be 
a)

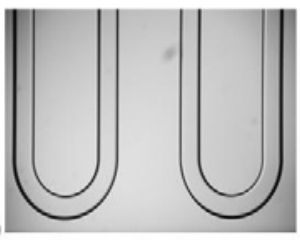

Microchannel

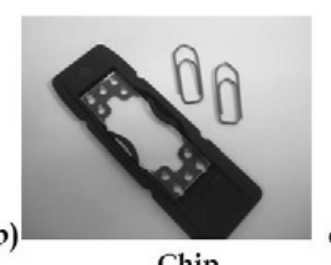

Chip

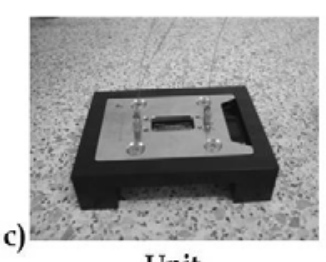

Unit

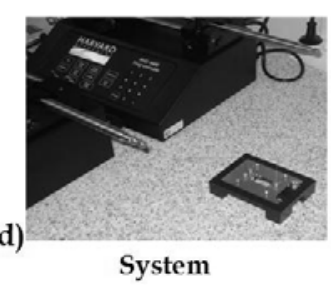

Fig. 1. Basic structural units of microreactor system.

a)
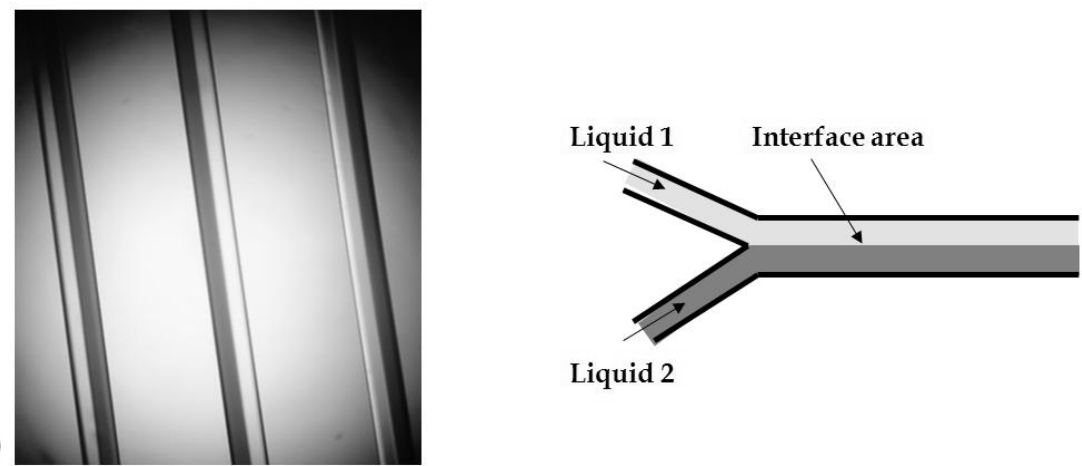

Liquid 2

Liquid 1

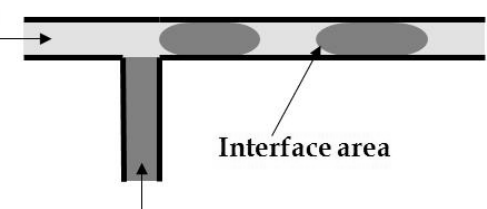

Liquid 2

b)

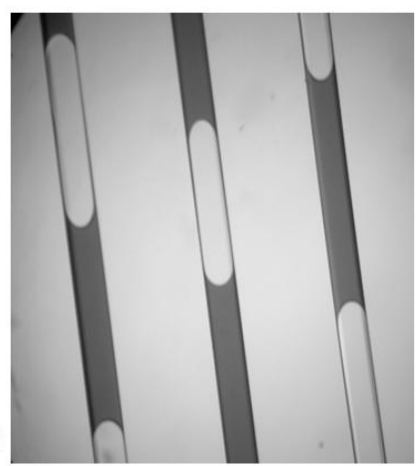

Fig. 2. Flow patterns; (a) parallel flow, (b) slug flow.

additionally divided into a single phase or a multiphase flow. When a multiphase flow is developed, two or more phases are separately added to the reactor where they form different flow patterns. When using a liquid-gas system in the microreactor a number of different flow patterns may be distinguish: bubble flow, slug (Taylor) flow, annular flow, spray flow, foam flow and transitional regimes (Sobieszuk et al. 2010). For the liquid-liquid system the most typical are a parallel and slug or segmented flow (Kashid 2007, Dessimoz et al. 2008) (Fig. 2). Slug flow in a microchannel is a flow characterised by a series of a liquid slugs of one phase separated by the other. The flow pattern formation depends on linear velocity (Burns and Ramshaw 2001), ratios of the phases, fluid properties, the channel geometry (Kashid 2007, Kashid and Agar 2007) and the construction material of the microreactor; all these parameters have to be considered when controlling the flow pattern.

Also, one of the most important properties of a microreactor is the high surface-to-volume ratio. Because of it, on the microscale it is possible to perform extremely rapid and high exothermic reactions as well as making the mass transfer distance very low. Specific surfaces of the microchannel 
Table 1. Comparison of macro- and micro-heat exchange systems.

\begin{tabular}{lccc}
\hline Parameter & $\begin{array}{c}\text { Shell and tube heat } \\
\text { exchanger }\end{array}$ & Compact heat exchanger & $\begin{array}{c}\text { Microchannel heat } \\
\text { exchanger }\end{array}$ \\
\hline $\begin{array}{l}\text { Surface-to-volume ratio } \\
{\left[\mathrm{m}^{2} / \mathrm{m}^{3}\right]}\end{array}$ & $50-100$ & $850-1500$ & $>1500$ \\
$\begin{array}{l}\text { Heat transfer coefficient } \\
\text { (liquid) }\left[\mathrm{W} /\left(\mathrm{m}^{2} \mathrm{~K}\right)\right]\end{array}$ & $\sim 5000$ (tube side) & $3000-7000$ & $>7000$ \\
$\begin{array}{l}\text { Heat transfer coefficient } \\
(\text { gas })\left[\mathrm{W} /\left(\mathrm{m}^{2} \mathrm{~K}\right)\right]\end{array}$ & $20-100$ & $50-300$ & $400-2000$ \\
Approach temperature $\left[{ }^{\circ} \mathrm{C}\right]$ & $\sim 20$ & $\sim 10$ & $<10$ \\
Flow regime & Turbulent & Turbulent & Laminar \\
\hline
\end{tabular}

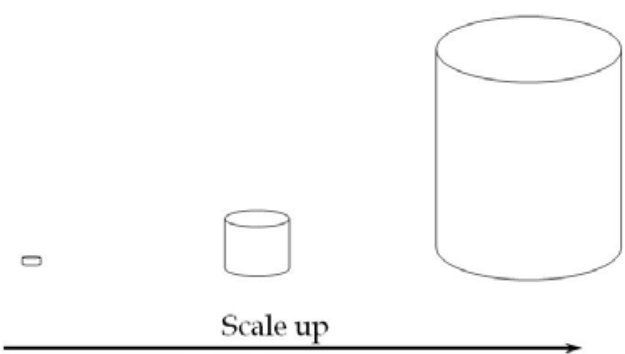

Numbering up

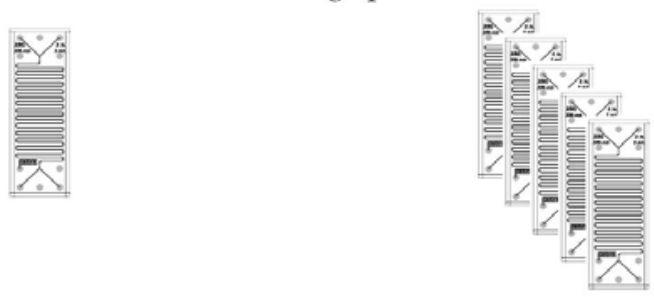

Fig. 3. Comparison of scale-up methodology in macroreactor and microreactor system.

amount from 10,000 to $50,000 \mathrm{~m}^{2} / \mathrm{m}^{3}$. In comparison to that, typical laboratory and production vessels usually do not exceed $1000 \mathrm{~m}^{2} / \mathrm{m}^{3}$ and $100 \mathrm{~m}^{2} / \mathrm{m}^{3}$ (Ehrfeld et al. 2005). This significant increase in the surface area relative to the volume will dramatically affect the transfer of mass, momentum and energy. Because of the high surface to volume ratio in microchannels, heat transfer is very efficient and reaction temperatures in microreactors can be regulated by very effective heat removal or application (Pohar and Plazl 2009). As a result, the heat transfer coefficient measured in a microreactor goes up to $25,000 \mathrm{~W} /\left(\mathrm{m}^{2} \mathrm{~K}\right)$. This exceeds those of conventional heat exchangers by at least one order of magnitude (Ehrfeld et al. 2005). A comparison between the micro and macro heat exchange system is presented in Table 1.

The excellent heat transfer characteristics of microfabricated devices also avoid the risk of potential significant industrial accidents caused by a thermal runaway (Chován and Guttman 2002). 


\section{Numbering up}

Numbering-up or scale-up (Fig. 3) was among the major predictions on microreactors benefits made in pioneering and was later a topic of in-depth industrial analysis on process intensification (Schenk et al. 2004). Connecting microreactors to operate in parallel or in a series of compact microplants could be built-up (Löwe et al. 2002, Carpentier 2005).

There are two ways to perform numbering up: external and internal. External numbering-up refers to a parallel connection of many devices. The advantage of this type is the possibility to use standard process-control equipment but because of the disadvantages like fluid equipartition, high costs of fabrication and material, internal numbering-up is proposed as an alternative. Internal numbering-up means the parallel or the serial connection of the functional elements only, rather than of the complete devices (Fig. 4). These elements are usually packed in a housing that contains one flow manifold and one collection zone (Schenk et al. 2004). When to use one or the other principle, depends on the reaction or process performed in the microchannel.

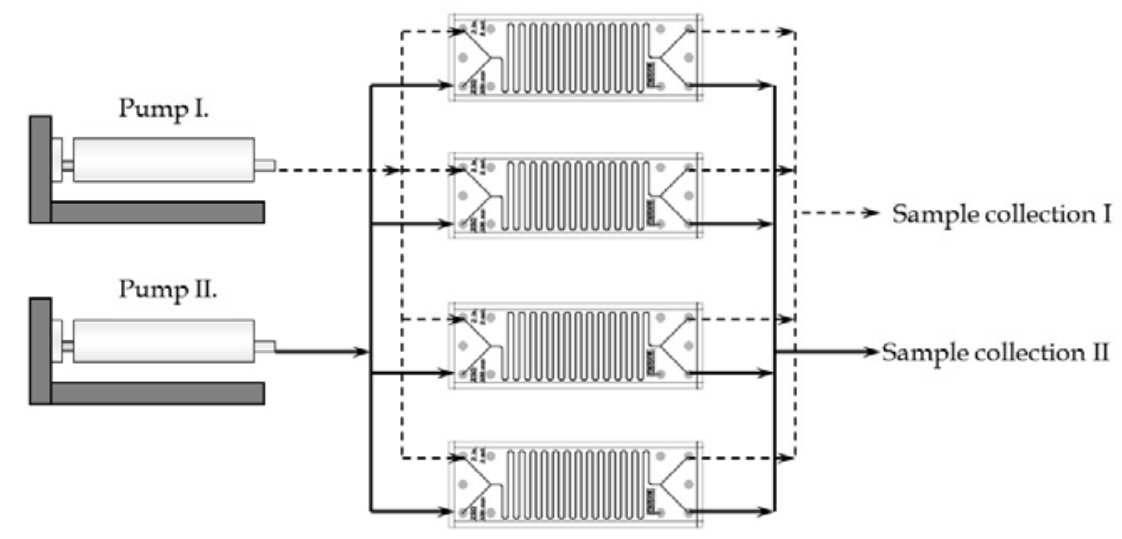

Microractors connected in to a parallel

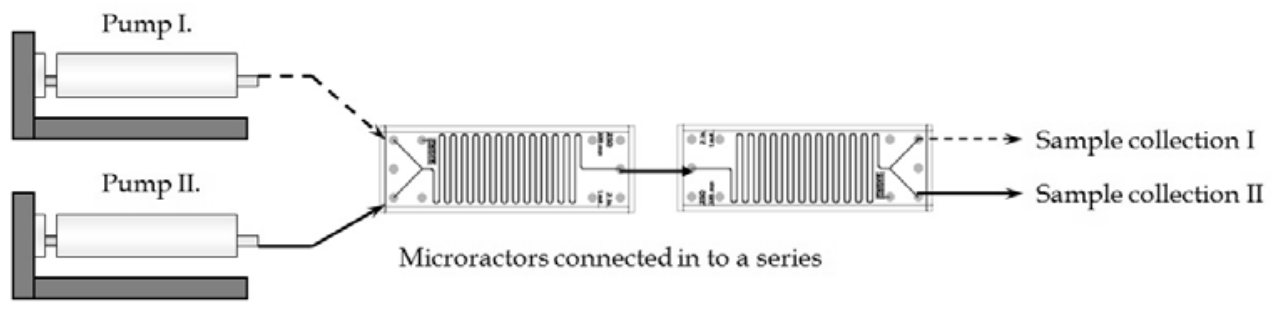

Fig. 4. Simplified methodology of serial and parallel numbering-up.

In comparison to scale-up, one of the biggest advantages of numbering-up operation systems is that continuous operation is uninterrupted if one of the units fail, because it can easily be replaced without effecting the other operating units. Another advantage is that unit operation development meaning timeframes needed for the setup, testing and turnaround are much smaller than in the traditional technology development. Once the process is described in a single chip, by combining the same units we can increase the capacity.
Micro-total-analysis-system or lab-on-chip

In the last few years, together with numbering up and microplant development, a great part of research investigation is focused on integrated micro-systems, the so called micro-total-analysis-systems ( $\mu$-TAS) or lab-on-chip (LOC); $\mu$-TAS includes pumps, valves, mixers, reactors and separators (Santini et al. 2000) so those devices can perform sampling, sample preparation, detection and data processing in an integrated manner (Fletcher et al. 2002, Tanaka et al. 2006). Performing biochemical reactions within 


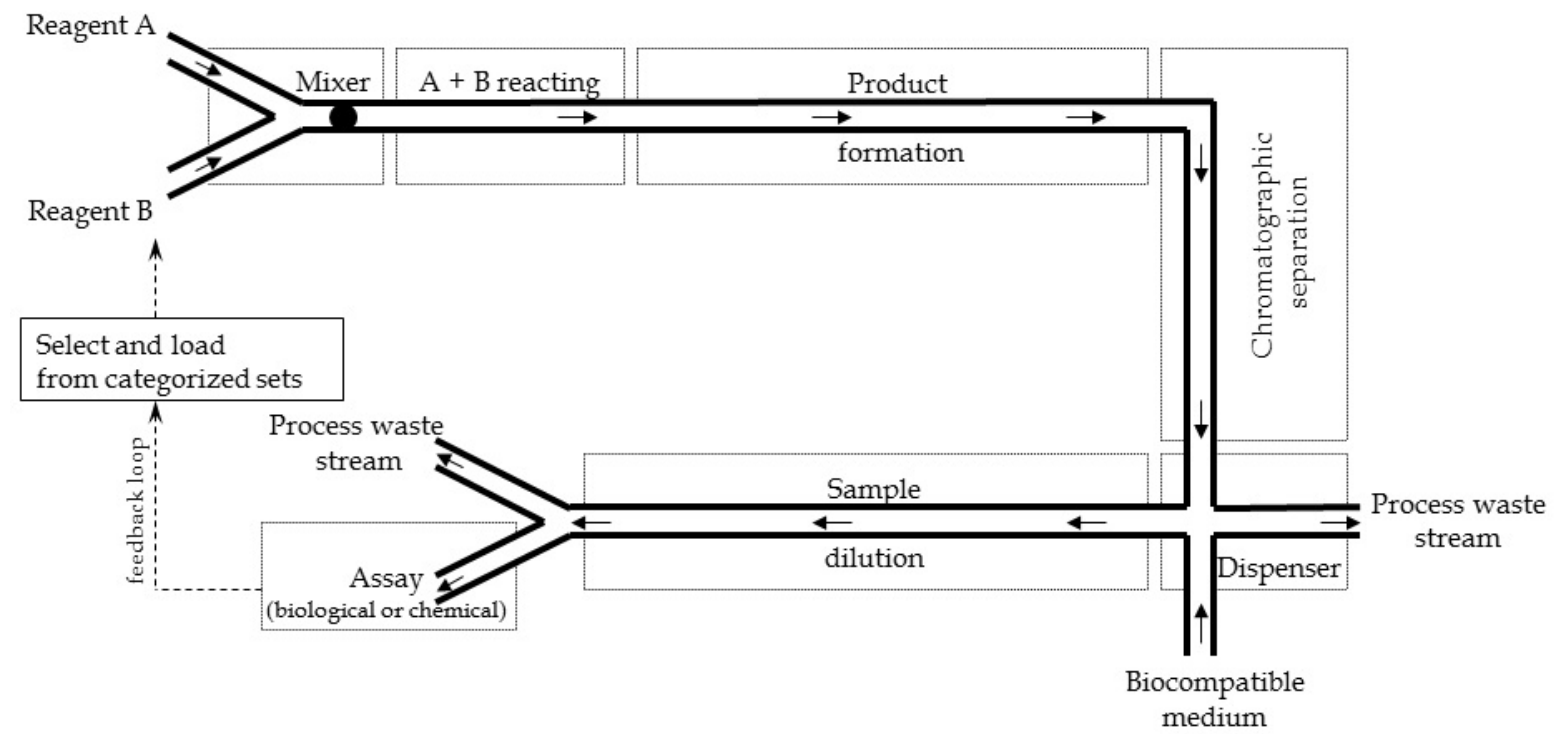

Fig. 5. Micro-total-analysis-system diagram ( $\mu$-TAS).

microfluidic systems also provides the opportunities to perform real time separation (Watts and Haswell 2003).

Optimally, such devices would automatically perform sampling, sample preparation, separation, detection and data processing in a fully integrated manner (Fig. 5). In addition these devices offer potential as remote controlled systems, which could be placed in inaccessible locations for continuous monitoring of processes (Fletcher et al. 2002). The most popular area of $\mu$-TAS research has been in the biomedical field, particularly in genomics and proteomics where it has been used in the analysis of both DNA and proteins. The miniaturization of chemical reactors offers many advantages of relevance to the pharmaceutical industry, which is constantly searching for high-throughput methods of producing products with a high degree of chemical selectivity (Watts and Haswell 2003). To enable this technology to function, different evolving technologies like microlithography, micro-electromechanical-systems (MEMS) technology, microfluidics and nanotechnology are being developed in parallel (Zhang et al. 2006).

Micro-electro-mechanical-systems (MEMS) technology refer to the miniaturization process of biological and chemical analytical devices and biosensors that show promising results in many fields of application from detection of pathogens, to environmental pollutants detection. A general approach of these systems is based on microcomponent unit operations such as micromixers, micro heat exchangers, microadsorbers, microchannel catalytic reactors, microseparators etc. The main advantage is that these systems can provide a high level of control over temperature and the consequent reaction, in addition to thermal integration and parallel operation (Chován and Guttman 2002). In the biomedical field, microseparation and microfiltration systems, used for sample pre-treatment are of special interest.

\section{Microreactor disadvantages}

Taking into consideration all mentioned microreactor advantages, it is obvious that they have many areas of application but those systems are still not perfect. There are some problems that occur when working with microreactors. Frequently quoted disadvantages of microreactors are high fabrication cost, low throughput, incompatibility with solids and the omission of cost reduction by scale up effects which lead to still poor industrial acceptance (Westermann 2009). To insure stable flow in a microreactor it is necessary to use low pulse or pulseless pumps; pumps are one of the most expensive parts of the microreactor apparatus. Due to the small dimensions of microchannels one of the biggest problems is clogging (Poe et al. 2006) when working with small diameter solids (for example enzyme dispersion) in a microreactor or with highly viscous solvents clogging can occur. It is also important to mention that when working with microreactors a very short residence 
time can be achieved, so it is necessary to perform a fast reaction. Fast reactions also require very active catalysts that are stable in the microreactor. So microreactors still, cannot be used as a replacement for all traditional processes. Another very important problem is analytics. By the number of applications, off-line analytics is used so sometimes a very long time period is necessary for gathering a sufficient amount of samples for performing the analysis. Therefore, there are many efforts in developing on-line analytical techniques for microstructured devices.

\section{APPLICATION OF MICROREACTOR IN MEDICINE AND BIOMEDICINE}

A great number of papers have been published on the application of microreactors not only in the field of fundamental laboratory research but also in the field of medicine and biomedicine. They have been developed in order to facilitate production and routine work in analysis. The general opinion is that the pharmaceutical and fine chemical industry could benefit from this technology approach, especially since it is important to develop new technologies that enable rapid synthesis, screening, production and metabolic studies of novel chemical entities and to reduce the development costs that are extremely high.

From the medicine and biomedicine point of view, clinical diagnostic devices are leaning towards completely integrated, multiple sophisticated biochemical analysis (PCR amplification, cell lysis, separation and detection) all on a single platform and in real time. The ability to miniaturize entire biomedical systems has the potential to reduce the cost of health-care management. There is also special attention paid to the usage of microdevices in tissue engineering and microengineering development. Tissue engineering is one of the most promising fields that can lead to in vitro tissue and organ reconstruction ready for implantation. Tissue scaffold is essential framework that provides an initial cellular support necessary for an appropriate cell density and functionality in tissue engineering. Implementing microreactor scaffolds cell migration could be altered together with proliferation and differentiation to achieve functional tissue replacement. Necessary nutrients can also be provided together with the removal of cellular waste through a microfluidic network (Leclerc et al. 2006). On the other hand, microengineering neural development is taking in advantage of all microfluidics properties to achieve better interaction between target cells. Researchers hope that this investigation will give better and precise insight of the nervous system, form neurogenesis and neuronal migration to axonal path-finding and synapse forming (Gomez 2000).

High throughput screening (HTS)

One of the most important applications of the microreactor system especially the LOC is the high throughput screening (HTS) for combinatorial chemistry, gene and protein analysis etc. The polymerase chain reaction (PCR) microchip/ microdevices, together with the capillary electrophoresis (CE) microchips and the hybridization microchips are studied rapidly. They could be used for fast DNA replication, microbial detection, biological agents and diseases diagnostics including infectious diseases like the human immunodeficiency virus (HIV), the human papillomavirus (HPV), the hepatitis virus and other (Zhang et al. 2006). To enable this technology to function, different evolving technologies like microlithography, micro-electromechanical-systems (MEMS) technology, microfluidics and nanotechnology are being developed in parallel (Zhang et al. 2006).

\section{Target molecules separation}

Devices that are used for separation in microreactor technology are based on extraction, filtration and diffusion processes. Usually they are designed as parts of different analytical systems and not as single instruments.

In biotechnology and chemistry, extraction of target molecules from a primary liquid and concentration of these molecules in a secondary liquid is an essential operation process performed before further analysis. Extraction processes, performed in microextractors, are based on the contact of two immiscible fluids (usually a combination of organic and inorganic fluids) and the resulting solute between the two phases. Up to now different solutions have been proposed like immiscible liquids co-flowing in groves and separated by micro-ridges, microporous membranes, co-flowing immiscible liquids separated by interfaces anchored on micro-pillars and more recently droplets continuously flowing through the concentrating liquids (Berthier et al. 2009). The very important field of microsepation is sorting specific biological targets from complex mixtures. Adams et al. (2008) reported the design and fabrication of the multitarget magnetic activated cell sorter. The mentioned device incorporates microfabricated ferromagnetic stripes to generate a magnetic field within the microchannel.

Microfiltration is performed by micromembranes and microfilters that are typically used to remove 
particles in the range of $0.1-10 \mu \mathrm{m}$ from a suspension. This action is usually taken before the suspension is pumped into microchannels. The main reason is that microreactors inherently suffer from clogging if particle solutions are employed or generated. A simple filtering step in advance of the reaction may help to prolong the operational life-time of a microreactor.

Different processes based on diffusion are developed on a microscale. They are mainly used in biotechnology and system biology. Some of them are capillary electrophoresis, ultra-thin layer gel electrophoresis, micro column liquid chromatography etc. Capillary electrophoresis is based on the difference in mobility of analytes in the electric field. After the development of non-gel sieving based capillary zone electrophoresis and after overcoming the problems like washing the capillary and the refilling the gel, this methodology became crucial for DNA sequencing. Besides that, it is now widely utilized for analysis of genotyping such as single standard conformation polymorphisms, single nucleotide polymorphisms and various kinds of mutations, metabolic studies (Cheng et al. 2006), proteomic analysis, single cell analysis etc. (Liu et al. 2006).

\section{Drug discovery and testing}

There has been great interest is using microfluidic systems as a valuable tool for discovering of many drugs. When compared to the equivalent bulk reactions, reactions performed in the microreactor invariably generate purer products in much shorter time. As mentioned, many chemical reactions that have been demonstrated improved reactivity, product yield and selectivity when performed in microreactors in comparison to those produced by traditional laboratory practice (Watts and Haswell 2003). The microfluidic channel can also be used for testing target selection, leading identification and optimization and preclinical testing and dosage developments (Kang et al. 2008). Roberge et al. (2005) claims that $50 \%$ of the reactions in the fine chemical or pharmaceutical industry could benefit from a continuous process based mainly on microreactor technology, and for the majority (44\%) a microreactor would be the preferred reaction device. System integration is also one of the most important roles of miniaturization; it will lead to better process control and intensification (Chován and Guttman 2002). Once a microreactor is optimized it can easily be introduced into an industry. One of the most challenging tasks in drug discovery is predicting pharmacokinetic behaviour in humans. For this purpose cell based microfluidic devices are used.
They can be useful for accessing the interaction within normal and diseased cells together with simulating and recreating cell-cell interactions that are present in living organisms. Another application is to test the synergistic effects of combinatorial drugs. Combinatorial drugs offer new hope for a number of diseases, but the range of possible combinations is too large to be investigated in expensive clinical studies (Kang et al. 2008). Today the isolated human hepatocytes are used for first drug screening. To ensure hepatocytes stability microdeviceds are used to test nutrient, oxygen, metabolic waste and new drug concentration gradients (Maguire et al. 2009). Microscale devices have the potential to be used for the analysis of the desired in vivo system.

\section{Cell investigation and single cell experimentation} Cell sorting, cell lysis, single cell analysis (Huang and Rubinsky 2001) and non-destructive single cell experiments on just one microreactor, the LOC platform is now possible. The success of LOCs was initially determined by their enhanced analytical performances: their fast, highly sensitive and reproducible analysis, with low consumption in chemical energy. Cell sorting based on the fluorescence path of the cells, cell size, specific proteins expressed on their surface or electrical properties are usually used (Kovac and Voldman 2007). For the next step, cell lysis, chemical, electrical, optical, mechanical or thermal is incorporated into a platform. The possibility of controlling the spatial and temporal cues to which cells are exposed, necessary for non-destructive single cell experimentation and analysis (Le Gac and van der Berg 2009) in combination with the dimensions of the microchannel that is highly compatible with the size of the biological cells is what makes LOC so interesting. Using this technology it is possible to get information about the behaviour of a single cell which is not possible during study at a large scale (Dragavon et al. 2008, Le Gac and van der Berg 2009) where the main problem is the long diffusion time that is necessary for a reagent to access the cell and then to provide feedback information (Tanaka et al. 2006). This problem is overcome in microreactors where diffusion impact is negligible. Microchannel devices can be useful in imitating the biological reaction apparatus, such as cellular surface and vascular systems, by providing the advantages of reduced space and laminar flow (Miyazaki and Maeda 2006). By using a microfluidic approach (using microinjections) the problem of delivery of molecules across the cell membrane for many experimental biological protocols can be solved (Adamo and Jensen 2008). 
Since the scale of liquid microspace inside the LOC devices is fitted to the size of the cells, microchip technology has several advantages for cellular biochemical analysis. The small internal dimensions found in LOC devices enable the trapping of individual cells and the investigation on long-lasting processes. In comparison, conventional cell studies on large scale require a large cell population and they don't reveal the behaviour of a single cell. A cell grown in a culture is used in a variety of contexts such as cell biology, tissue engineering, biomedical engineering, and pharmacokinetics for drug development. Microtechnology facilities the study of cell behaviour in vivo because it provides the necessary tools for recreating in vivo-like microenvironments (Chiu 2001, Walker et al. 2004). Microfluidics cell culture platforms can be divided into: (i) a single cell-type culture and (ii) a multiple cell-type culture (Huang et al. 2010).

In its simplest form a microchip for cell cultivation consists of two small access holes for an inlet and outlet of reagents and a large hole for cell introduction (Fig. 6).

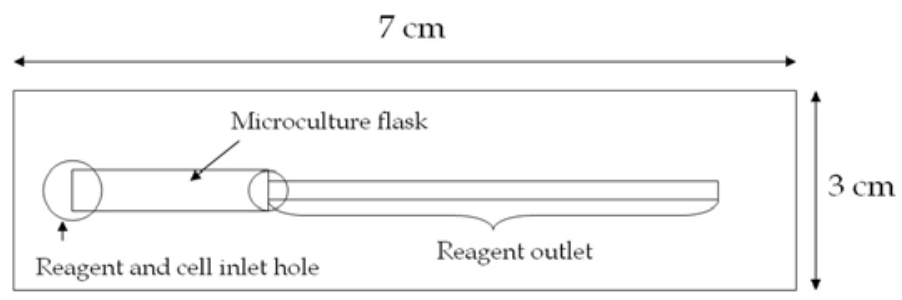

Fig. 6. Illustration of the microchip for cell culture (Tanaka et al. 2006).

Combining this simple form with different LOC technologies cell sorting, cell lysis and single cell analysis and non-destructive single cell experimentations could be performed as previously described in the section on LOC application. El-Ali et al. (2005) described the microfluidic device with rapid stimulus and lysis of mammalian cells for resolving fast transient responses in cell signalling networks.

The next new step is the concept of a "lab-in-a-cell" (LIC) where the single cell is used as an experimental unit. The concept relies on the basic idea of utilizing a powerful cellular factory for experimental purposes. The first advantage of this system is that a cell performs many more operations and functions that could ever be integrated into a single LOC device. The second is that all occurring processes are ruled by diffusion so there is request for additional mixing and pumping devices. To make this system work, three main tasks should be fulfilled: cell handling (placement of cells in precise locations), cell characterisation (ability of tools for real time characterisation of a single cell) and accessing intracellular content (the possibility of crossing cellular content and inside monitoring). Different principles and methods crucial for LIC experimentation are mentioned in Table 2.

\section{Biomolecule analysis}

A great number of microeractors application refers to protein and peptide mapping together with nucleic acid analysis. In protein analysis the most frequently used enzyme is trypsin which catalyses the process of protein digestion through the hydrolysis of peptide. The analysis of nucleic acids relays on the polymerase chain reaction (PCR) and amplification of DNA on the microscale. By combining these principles together with preparation, screening, detection etc. more complex devices called micro-total-analysis-systems ( $\mu$-TAS) or lab-on-chip (LOC) are developed.

Using microfluidic devices, it is also possible to perform high throughput analysis of different biomolecules like proteins, nucleic acid, amino acids, DNA, peptide mapping etc. The analysis of genetic material typically calls for first the amplification of the DNA sample and then its detection. The amplification of DNA is usually performed by a polymerase chain reaction (PCR) based on the reconstruction of each double helix. A major advantage of miniaturizing PCR systems is the fact that a much lower thermal mass of the reaction chamber allows for much rapid heating and cooling and thus a much faster process overall. Beside that, it is possible to integrate heaters and temperature 
Table 2. Micro- and nano-fluidic tools and protocols essential for LIC experimentation (Le Gac and van der Berg 2009).

\begin{tabular}{|c|c|c|c|}
\hline & Technique & Principle & Reference \\
\hline \multirow{4}{*}{ 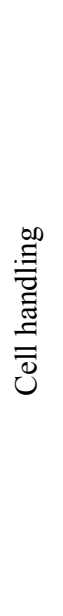 } & $\begin{array}{l}\text { Mechanical and } \\
\text { chemical trapping }\end{array}$ & $\begin{array}{l}\text { Mechanical trapping includes lateral and planar trapping } \\
\text { using side structures or microapertures or microwells } \\
\text { located under the cells. Chemical trapping relies on } \\
\text { formation of extracellular matrix proteins on which cells } \\
\text { are immobilised. }\end{array}$ & $\begin{array}{l}\text { Kurosawa et al. } 2006 \\
\text { Thery and Bornens } 2006 \\
\text { Dragavon et al. } 2008 \\
\text { Skelley et al. } 2009\end{array}$ \\
\hline & $\begin{array}{l}\text { Electrical } \\
\text { manipulation }\end{array}$ & $\begin{array}{l}\text { Method involves electrophoretic or dielectrophoretic } \\
\text { methods which explode negative charges at the cell } \\
\text { surface and its dielectric properties. }\end{array}$ & $\begin{array}{l}\text { Ozkan et al. } 2003 \\
\text { Tresse and Takeuchi } 2004 \\
\text { Taff and Voldman } 2005\end{array}$ \\
\hline & Optical manipulation & $\begin{array}{l}\text { Laser generated force is used for precise 3D } \\
\text { displacement of cell. }\end{array}$ & Piggee 2009 \\
\hline & Alternative techniques & $\begin{array}{l}\text { Magnetic trapping in based on cell attachment to } \\
\text { magnetic beads. } \\
\text { Usage of droplets where the substrates are scattered by } \\
\text { cells. }\end{array}$ & $\begin{array}{l}\text { El-Ali et al. } 2005 \\
\text { Adams et al. } 2008\end{array}$ \\
\hline \multirow{4}{*}{ 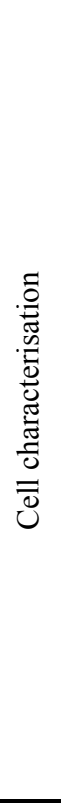 } & $\begin{array}{c}\text { Optical } \\
\text { characterisation }\end{array}$ & $\begin{array}{l}\text { Fluorescent proteins like green fluorescent protein, due } \\
\text { to their stability have been employed for cell tracking. } \\
\text { Other approaches are nanoparticles used for high } \\
\text { resolution imaging and thermal lens microscopy that } \\
\text { relies on the molecular adsorption properties in the } \\
\text { visible and UV range. }\end{array}$ & $\begin{array}{l}\text { Lidke et al. } 2004 \\
\text { Valero et al. } 2008\end{array}$ \\
\hline & Biochemical sensing & $\begin{array}{l}\text { Using electrical sensors or combination of electrical and } \\
\text { optical measurements, various parameters like } \mathrm{pH} \text {, } \\
\text { temperature, } \mathrm{O}_{2} \text { concentration can be obtained. Also } \\
\text { with the possibility of fabrication sensing structures on } \\
\text { the nanoscale opens the possibility to subcellular and } \\
\text { intracellular measurements. }\end{array}$ & $\begin{array}{l}\text { Cheng et al. } 2006 \\
\text { Guenat et al. } 2006 \\
\text { Krommenhoek et al. } 2007\end{array}$ \\
\hline & Patch-clamping & $\begin{array}{l}\text { Patch-clamping involves ion channels that become } \\
\text { interesting because of their accessibility on the cell } \\
\text { membrane and possibility to be automated and } \\
\text { parallelized. }\end{array}$ & $\begin{array}{l}\text { Fertig et al. } 2002 \\
\text { Ionescu-Zanetti et al. } 2005\end{array}$ \\
\hline & Mechanical sensing & $\begin{array}{l}\text { Information is derived from the mechanical properties of } \\
\text { a cell membrane because these are altered in response to } \\
\text { specific stimuli during the cell cycle and development. }\end{array}$ & Waconge et al. 2008 \\
\hline \multirow{3}{*}{ 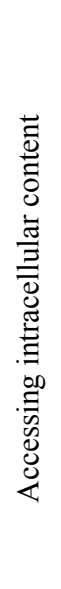 } & $\begin{array}{l}\text { Crossing the cell } \\
\text { membrane }\end{array}$ & $\begin{array}{l}\text { Combination of different paermeabilization technique on } \\
\text { the membrane (electroporation, pore-inducing } \\
\text { chemicals, high energy laser pulses) and LOC } \\
\text { methodology enhances poration performances. Another } \\
\text { approach for crossing membrane obstacle is piercing cell } \\
\text { membrane with a sharp structure. }\end{array}$ & $\begin{array}{l}\text { Huang and Rubinsky } 2001 \\
\text { Adamo and Jensen } 2008\end{array}$ \\
\hline & $\begin{array}{l}\text { Nanochanneles and } \\
\text { nanopumping }\end{array}$ & $\begin{array}{l}\text { Nanochannles and nonopumping are essential for the } \\
\text { manipulation of subcellular liquid volumes. }\end{array}$ & $\begin{array}{l}\text { Tas et al. } 2002 \\
\text { Hoang et al. } 2009\end{array}$ \\
\hline & Cell fussion & $\begin{array}{l}\text { Method is based on fusion with a vesicle or another cell } \\
\text { to achieve material introducing in to cell. Electrofusion } \\
\text { benefits from LOC technology because it brings a higher } \\
\text { degree of control over the different steps of cell } \\
\text { alignment, pairing and fusion. }\end{array}$ & Chiu 2001 \\
\hline
\end{tabular}


sensors into the same chip to improve temperature control and process efficiency (Slyadnev et al. 2008). Microtechnology is also used for the determination of a precise DNA molecule code.

For gene microarray experiments, probe DNA or oligomer chains are immobilised to a solid surface. Different chains of DNA or oligomer sequences are localised to separate a specific molecule. The target (free DNA or RNA) is labelled with fluorescent markers and hybridized to the microarray. The array is scanned and images are interpreted. Microarray systems vary in the type of polynucleic acid immobilised, the methods of immobilisation, nucleic acid formation (on chip or ex situ), hybridisation and reading of the hybridised array (Sanders and Manz 2000). Microfluidic DNA amplification can be performed in continuous flow microPCR and microfluidic in PCR droplets (Fig. 7). Continuous flow microPCR strongly depends on optimisation of the device design and operating flow rates (Zhang and Ozdemir 2009). Chip based microPCR devices can be classified into two types: well based PCR chips and continuous flow PCR chips. In well-based PCR, the PCR mixture is injected into the well and then the whole chip, including the sample, is heated and cooled through specific thermal-cycling temperatures. Continuous-flow microPCR moves the sample through fixed temperature zones to achieve the required thermal-cycling (Sanders and Manz 2000). Recently, the microdroplet technology has been applied in continuous-flow microPCR, where the PCR effectively occurs within droplets, so that not only PCR inhibition but also carryover sample contamination will be eliminated. In comparison with the conventional continuous-flow microPCR devices, which use a single aqueous phase, the droplet technology can further reduce thermal mass and thus shorten the thermal-cycling process. Lately single molecules studies are being performed on an even smaller scale than micro, using nanochannels (Hoang et al. 2009). Interactions of single DNA and protein molecules were studied in $120 \mathrm{~nm} \times 150 \mathrm{~nm}$ fused silica channels (Wang et al. 2005).

Recent expansion in the use of DNA chips and capillary electrophoresis has had an effect on the further development of immunoassay chips. Microchips open new possibilities in immunoanalysis applications. Most steps of the immunoassay procedure can be integrated within a simple chip (Přibyl et al. 2004). Immunoassay is the main analytical technique used in the study of infectious diseases and clinical endocrinology, due to the high sensitivity and selectivity of the antigen-antibody reaction. With development of lab-on-chip technology, miniaturisation of the immunoassay has become very interesting (Xiang et al. 2006).

Peptide mapping in which proteins are identified and characterised, is another interesting field of microreactor application. The mapping finds applications in different fields from quality control to proteomics.

Most of the microreactors described in this field are built as detached biocatalytic chambers. Enzymes in them, for protein digestion are chemically immobilised, trapped or physically adsorbed to a support (Bossi et al. 2004). The most frequently used enzyme is trypsin, the enzyme catalyzing the process of protein digestion through hydrolysis of peptide bonds at a basic residue.

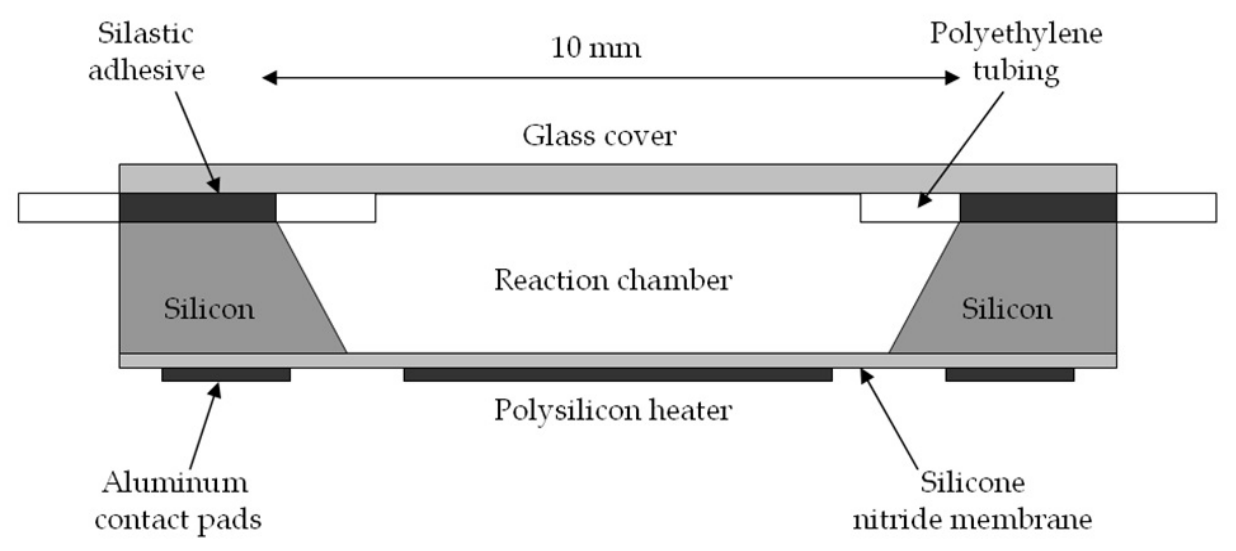

Fig. 7. Micromachined PCR chamber (Northrup et al. 1993). 


\section{Metabolic studies}

In the last decades there has been great interest in syntheses of new molecules as potential drugs. These potential drug substances need to be tested for their adsorption, distribution in the metabolism, elimination and toxicity (ADMET). These properties are usually studied using cell cultures of live animals, but this method is quite expensive and requires long time periods. To eliminate the mentioned problems some microfluidic devices have been developed. Zguris et al. (2005) described a microreactor with microsomes entrapped in a polymer matrix of poly(ethylene)glycol for determination of metabolic products of a potential drug substance. The microsomes were derived from ultrasonic homogenisation of the human liver, and they retained the properties of the liver. They showed that fewer microsomes than hepatocytes are needed to generate the same level of its activity. Mass transfer of drug delivery was characterized by calculating the mesh size of the hydrogel, and metabolic activity was measured using a fluorescent reporter for cytochrome P450.

Metabolic measurements of glucose consumption and production of ammonia via glutamine metabolism were estimated using enzymatic reactions and direct and indirect absorbance measurements, respectively (Kraly et al. 2009).

There is a large interest in the development of microfluidic devices as a tool for metabolic profiling, metabolomics and other metabolite related biological studies. Many approaches for metabolomic analysis utilize high-resolution separation techniques such as capillary electrophoresis. As other microfluidic devices, microchip capillary electrophoresis ensures rapid analysis times, small reagent and sample consumption, portability and low costs (Kraly et al. 2009). Liquid chromatography is also commonly used for metabolic studies; it ensures highly effective separation. The biggest advantage of microchip capillary electrophoresis $(\mathrm{CE})$ is the ability to perform parallel-array or multi-dimensional analysis (Loughran et al. 2005). Guenat et al. (2006) presented a generic platform for cell culture able to monitor extracellular ionic activities for real time monitoring of cell-based responses. Measurement of different ion concentrations in cell cultures is important for understanding cellular signalling and metabolism.

Ion channels are an important field of research due to the fact that those places in the cell serve as true targets. Using micro technology the research is becoming more and more simplified; automated microstructured devices for whole cell patch clamping is one of the advancements in that field (Fertig et al. 2002, Ionescu-Zanetti et al. 2005).

\section{Clinical diagnostics}

One of the major applications of microfluidic devices is for disease diagnostics. For example, cell sorting is a method included in many diagnostics tests. Sorting can be based on physical parameters (cell motility, size, deformability, biochemical markers) (Rivet et al. 2011). Traditionally flow cytometry, employing fluorescence detection [high-speed fluorescently activated cell sorting, FACS (Wlodkowic and Cooper 2010)], is used for measurement of the physical and chemical characteristics of cells. Lately many microfluidic flow cytometers using a variety of detection instruments have been developed (Yi et al. 2006). Cell surface markers can also be used for detection and diagnosis of a variety of diseases. Many microfluidic devices used surface coated with antibodies specific to cell surface markers to capture the cell of interest. Microfluidic devices are used for detection of circulating tumour cells, for cancer biomarkers as an epidermal growth factor and $\mathrm{CD}^{+}$ T-cells (Rivet et al. 2011). There has also been interest in developing microdevices for detecting protein concentrations in plasma (plasma protein profiles are often associated with human diseases). DNA analysis on-chip can be used for diagnosis of genetic basis. PCR base amplifications and analysis can ensure good insight in gene expression. PCR microfluidics insure a large number of parallel amplification analysis and can lead to more accurate information and a better understanding of the analysed processes (Zhang et al. 2006).

Lin et al. (2010) describes the specific use of microdevices for immunoassay tests. Immunoassays have a variety of formats, all of which make use of the sensitivity and specificity of this $\mathrm{AB}$ (antibody)-AG (antigen) interaction, which allows the quantification and monitoring of small molecules, such as drugs and metabolites, large proteins, nucleic acids, and even whole pathogens. The immunoassay tests include a series of washing, mixing and incubating steps, therefore they are quite time consuming. Also chemicals are very expensive, so miniaturisation can ensure expenses reduction. Microfluidic devices for immunoassays can be fabricated from a variety of materials. The most commonly used substrate materials are silicon, glass, and polymers. Liquid transport in those systems can be electroosmotic, pneumatic, electrowetting, centrifugal and piezoelectric.

The process of immunoassay on microchips is based on the immobilisation of ABS or AGS on the microchip surface. A scheme of the disc design microchip for immunoassay is given in Fig. 8.

Sun et al. (2009) used a microfluidic device to determine the level of antibodies in the serum of 


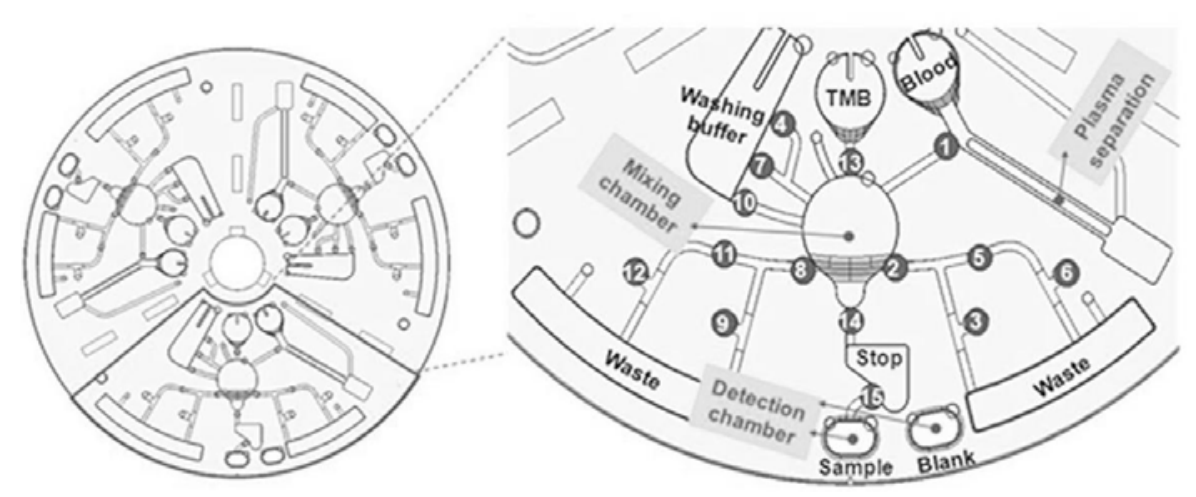

Fig. 8. Schematic illustrations of the disk design (Lin et al. 2010).

HIV-positive patients. The developed microfluidic network, replaced the 96-well plate. To improve the sensitivity of microfluidic assay for HIV, an ES membrane was integrated into the microchip improving proteins adsorption. Lawi et al. (2009) presented the microfluidic cartridge system for conducting complex heterogeneous proteomics and genomic assay experiments. The complex systems composed of a disposable microfluidic cartridge and a sensing and controlling instrument are used for clinical studies.
Another example is the use of a microchip for human papilloma virus (HPV) diagnosis (Vecchio et al. 2010). HPV infections are widely considered to be an important risk factor for the genesis of cervical cancer. Molecular biology methods are used for HPV virus detections (mainly polymerase chain reactions and hybridization tests). Due to a high parallelism of analysis miniaturized biochips are recognized to be suitable for HPV analysis. Vecchio et al. (2010) developed plastic, disposables, modular chip suitable for HPV diagnostics, by two sequential steps performed on the same device.

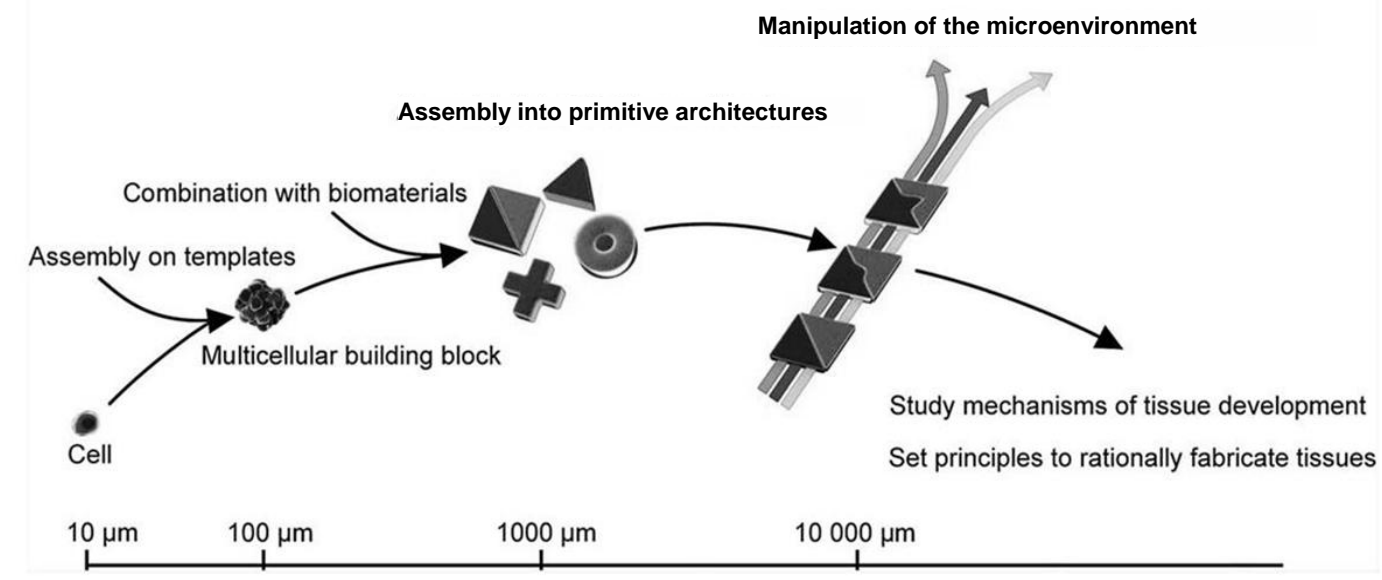

Fig. 9. From tissue assembly to tissue development (Rivron et al. 2009). 


\section{Tissue engineering}

While a large number of patients succumb to multiple organ failure in their final days, the majority of diseases in the current population result from damage, failure, or loss of a single organ or tissue component (Bhatia and Chen 1999). Tissue engineering is one of the promising fields; it may lead to in vitro tissue and organ reconstruction. Cartilage, bones and other organs are complex 3D tissues. Tissues scaffold ensures initial cell support to provide the development of cell population. Microchannels can be used for physical orientation of cell migration. Due to the nature of microfluidic devices, the continuous operating mode, nutrients and cellular waste can be removed. Engineered tissue should resemble as much as possible the in vivo structures (Leclerc et al. 2006). Microfluid devices provide a well organized microenvironment for multiple cell types (vascular systems and organ systems) (Marimuthu and Kim 2011).

Tissues are often a combination of small repeating units assembled over several scales. The rapid development of complex microfluidic systems, microbioreactors and detecting tools allows the long term culture of microscale tissues in a precisely defined microenvironment (Rivron et al. 2009). It is still great challenge; how to orchestrate the development mechanism in vitro. A scheme representing the process from tissue assembly to tissue development in vitro is shown in Fig. 9.

Leclerc et al. (2006) described the use of rectangular polydimethylsiloxane microchannels for growth of liver and kidney organotypic cultures. The study demonstrated the positive effect of a rectangular microchannel on an embryonic liver development on a hydrophobic surface. The authors mentioned that the advantage of microchannel scaffolds is that all the dimensions can be precisely controlled. Condie et al. (2007) presented the use of microchannels for immortalized osteoblast precursor adhesion. The idea stemmed from the problem that success and the lifetime of a bone implant depends largely on the degree of osteointegration at material-bone interaction; layer of soft tissue can accumulate at the surface of implanting materials, this can result in many problems. A microchannel was used to test the cells- materials complex interactions, suggesting that minimal width of a flat engineering biomaterial surface insures optimal integration with bone cells.

\section{CONCLUSION}

Microreactor technology has seen exponential growth over the last decade with applications in the felds of analytical chemistry, chemical synthesis, chemical engineering, biotechnology and biomedicine. The growth of microreactor technology could be attributed to their merits and unique operating characteristics compared to conventional technology.

The general opinion is that microfluidic and microreactor devices will bring revolution to the world of medicine. The combination of biomedicine and microfluidic technologies provides a unique opportunity to fully exploit the potential of microfluidic technologies and to expend our knowledge of biological systems through precise control of the reaction environment. Cell sorting, cell lysis and single cell analysis and non-destructive single cell experiments on just one microreactor, clinical devices, tissue engineering on a microscale are already our reality and the future developments and expectations look even more promising.

\section{ACKNOWLEDGEMENT}

This work was financially supported through The National Foundation for Science, Higher Education and Technological Development of the Republic of Croatia.

\section{REFERENCES}

Adamo A, Jensen KF. Microfluidic based single cell microinjection. Lab Chip. 8: 1258-1261, 2008.

Adams JD, Kim U, Tom Soh H. Multitarget magnetic activated cell sorter. Proc Natl Acad Sci USA. 105: 18165-18170, 2008.

Bhatia SN, Chen CS. Tissue engineering at the micro-scale. Biomed Microdevices. 2: 131-144, 1999.

Berthier J, Van-Man Tran, Mittler F, Sarrut, N. The physical of coflow micro-extractor: Interface stability and optimal extraction length. Sens Actuators A Phys. 149: 56-64, 2009.

Bossi A, Guizzardi L, D’Acunto MR, Righetti, PG. Controlled enzyme-immobilisation on capillaries for microreactors for peptide mapping. Anal Bioanal Chem. 378: 1722-1728, 2004.

Burns JR, Ramshaw C. The intensification of rapid reactions in multiphase systems using slug flow in capillaries. Lab Chip. 1: 10-15, 2001.

Carpentier JC. Process intensification by miniaturisation. Chem Eng Technol. 28: 255-258, 2005. 
Cheng W, Klauke N, Sedgwick H, Smith GL, Cooper JM. Metabolic monitoring of the electrically stimulated single heart cell within a microfluidic platform. Lab Chip. 6: 1424-1431, 2006.

Chiu DT. A microfluidic platform for cell fusion-Commentary. Curr Opin Chem Biol. 5: 609-612, 2001.

Chován T, Guttman A. Microfabricated devices in a biotechnology and biochemical processing. Trends Biotechnol. 20: 116-122, 2002.

Condie R, Bose S, Bandyopadhyay A. Bone cell-materials interactions on $\mathrm{Si}$ microchannels with bioinert coatings. Acta Biomater. 3: 523-530, 2007.

Dessimoz A, Cavin L, Renken A, Kiwi-Minsker L. Liquid-liquid two-phase flow patterns and mass transfer characteristics in rectangular glass microreactors. Chem Eng Sci. 63: 4035-4044, 2008.

Dragavon J, Molter T, Young C, Strovas T, McQuaide S, Holl M, Zhang M, Cookson B, Jen A, Lidstrom M, Meldrum D, Burgess L. A cellular isolation system for real-time single-cell oxygen consumption monitoring. J R Soc Interface. 5(Suppl. 2): S151-159, 2008.

Ehrfeld W, Hessel V, Löwe H. Microreactors: new technology for modern chemistry. Wiley-VCH, Weinheim 2005, pp. 1-69.

El-Ali J, Gaudet S, Günther A, Sorger PK, Jensen KF. Cell stimulus and lysis in a microfluidic device with segmented gas-liquid flow. Anal Chem. 77: 3629-3636, 2005.

Fertig N, Blick RH, Behrends JC. Whole cell patch clamp recording performed on a planar glass chip. Biophys J. 82: 3056-3062, 2002.

Fletcher PD, Haswell SJ, Pombo-Villar E, Warrington BH, Watts P, Wong SYF, Zhang X. Micro reactors: principles and applications in organic synthesis. Tetrahedron. 58: 4735-4757, 2002.

Gerey K, Codée JDC, Seeberger PH. Microreactors as tools for synthetic chemists - The Chemists' round-bottomed flask of the $21^{\text {st }}$ century? Chem Eur J. 12: 8434-8442, 2006.

Gomez FA (ed.). Biological applications of microfluidics. Wiley-VCH, Weinheim 2000, pp. 291-404.

Guenat OT, Generelli S, de Rooji NF, Koudelka-Hep M, Berthiaume F, Yarmush ML. Development of an array of ion-selective microelectrodes aimed for the monitoring of extracellular ionic activities. Anal Chem. 78: 7453-7460, 2006.

Hernandez Carucci JR, Eränen K, Murzin DYu, Salmi TO. Experimental and modelling aspects in microstructured reactors applied to environmental catalysis. Catal Today. 147: 149-155, 2009.
Hoang HT, Sagers-Nolten IM, Bereschot JW, de Boer MJ, Tas NR, Haneveld J, Elwenspoek MC. Fabrication and interfacing of nanochannel devices for single-molecule studies. J Micromech Microeng. 19: 1-11, 2009.

Huang M, Fan S, Xing W, Liu C. Microfluidic cell culture system studies and computational fluid dynamics. Math Comput Model. 52: 2036-2042, 2010.

Huang Y, Rubinsky B. Microfabricated electroporation chip for single cell membrane permeabilization. Sens Actuators A Phys. 89: 242-249, 2001.

Ionescu-Zanetti C, Shaw RM, Seo J, Jan LY, Lee L.P. Mammalian electrophysiology on a microfluidic platform. Process Natl Acad Sci USA. 102: 9112-9117, 2005.

Kang L, Chung BG, Langer R, Khademhosseini A. Microfluidics for drug discovery and development: From target selection to product lifecycle management. Drug Discover Today. 13: 1-13, 2008.

Kashid MN. Experimental and modelling studies on liquid-liquid slug flow capillary microreactors. PhD Thesis, Dortmund 2007.

Kashid MN, Agar DW. Hydrodynamics of liquid-liquid slug flow capillary microreactor: flow regimes, slug size and pressure drop. Chem Eng J. 131: 1-13, 2007.

Kovac JR, Voldman J. Intuitive, image-based cell sorting using optofluidic cell sorting. Anal Chem. 79: 9321-9330, 2007.

Kraly JR, Holcomb RE, Guan Q, Henry CS. Review: Microfluidic applications in metabolomics and metabolic profiling. Anal Chim Acta. 653: 23-35, 2009.

Krommenhoek EE, Gardeniers JGE, Bomer JG, Li X, Ottens M, van Dedem GWK, van Leeuwen M, van Gulik WM, van der Wielen A, Heijnen JJ, van der Berg A. Integrated electrochemical sensor array for the online monitoring of yeast fermentation. Anal Chem. 79: 5567-5573, 2007.

Kurosawa O, Oana H, Matsuoka S, Noma A, Kotera $\mathrm{H}$, Washizu M. Electroporation through a micro-fabricated orifice and its application to the measurement of cell response to the external stimulus. Meas Sci Technol. 17: 3127-3133, 2006.

Lawi W, Wiita C, Snyder ST, Wei F, Wong D, Wong PK, Liao JC, Haake D, Gau V. A microfluidic cartridge system for multiplexed clinical analysis. J Assoc Lab Autom. 14: 407-412, 2009.

Le Gac S, van der Berg A. Single cells as experimentation units in lab-on-a-chip devices. Trends Biotechnol. 28: 55-62, 2009. 
Leclerc E, Corlu A, Griscom L, Baudoin R, Legallais C. Guidance of liver and kidney organotypic cultures inside rectangular silicone microchannels. Biomaterials. 27: 4109-4119, 2006.

Lidke DS, Nagy P, Heintzmann R, Arndt-Jovin D, Post JN, Grecco HE, Jares-Erijman EA, Jovi TM. Quantum dot ligand provides new insight into erbB/HER receptor-mediated signal transduction. Nat Biotechnol. 22: 198-203, 2004.

Lin CC, Wang CJH, Wu HW, Lee GB. Microfluidic immunoassays. Tech Rev.15: 253-274, 2010.

Liu BF, Xu BX, Zhang G, Du W, Luo Q. Micro-separation toward system biology. J Chromatogr A. 1106: 19-28, 2006.

Loughran M, Cretich M, Chiari M, Suzuki H. Separation of DNA in a versatile microchip. Sens Actuators B Chem. 107: 975-979, 2005.

Löwe H, Hessel V, Mueller A. Microreactors. Prospects already achieved and possible misuse. Pure Appl Chem. 74: 2271-2276, 2002.

Maguire TJ, Novik E, Chao P, Barminko J, Nahminas $\mathrm{Y}$, Yarmush $\mathrm{M}$, Cheng KC. Design and application of microfluidic systems for in vitro pharmacokinetic evaluation of drug candidates. Curr Drug Metab. 10: 1-8, 2009.

Marimuthu M, Kim S. Microfluidic cell coculture methods for understanding cell biology, analyzing bio/pharmaceuticals and developing tissue constructs. Anal Biochem. 413: 81-89, 2011.

McCreedy T. Fabrication techniques and materials commonly used for the production of microreactors and micro total analytical systems. Trend Anal Chem. 19: 396-401, 2000.

Miyazaki M, Maeda H. Microchannel enzyme reactors and their applications for processing. Trend Biotechnol. 24: 463-470, 2006.

Northrup MA, Ching MT, White RM, Lawton RT. DNA amplification with a microfabricated reaction chamber. International Conference of Solid-state Sensors and Actuators (Transducers 93), Yokohama, Japan, June 7-10, pp. 924-926, 1993.

Ozkan M, Pisanic T, Scheel J, Barlow C, Esener S, Bhatia SN. Electro-optical platform for the manipulation of live cells. Langmuir. 19: 1532-1538, 2003.

Piggee C. Optical tweezers: not just for physicists anymore. Anal Chem. 81: 16-19, 2009.

Poe SL, Cummings MA, Haaf MP, McQuade DT. Solving the clogging problem: precipitate-forming reactions in flow. Angew Chem Ed. 45: 1544-1548, 2006.

Pohar A, Plazl I. Process intensification through microreactor application. Chem Biochem Eng Q. 23: 537-544, 2009.
Přribyl M, Šnita D, Hasal P, Marek M. Modeling of electric-field driven transport processes in microdevices for immunoassay. Chem Eng J. 101: 303-314, 2004.

Rebrov EV, Duinkerke SA, de Croon MHJM, Schouten JC. Optimization of heat transfer characteristics, flow distribution, and reaction processing for a microstructured reactor/ heat-exchanger for optimal performance in platinum catalyzed ammonia oxidation. Chem Eng J. 93: 201-216, 2003.

Rivet C, Lee H, Hirsch A, Hamilton S, Lu H. Microfluidics for medical diagnostics and biosensors. Chem Eng Sci. 66: 1490-1507, 2011.

Rivron NC, Rouwkema J, Truckenmüller R, Karperien M, De Boer J, Van Blitterswijk CA. Tissue assembly and organization: developmental mechanisms in microfabrication tissue. Biomaterials. 30: 4851-4858, 2009.

Roberge DM, Durcy L, Bieler N, Cretton P, Zimmermann B. Microreactor technology: A revolution for the fine chemical and pharmaceutical industries? Chem Eng Technol. 25: 318-322, 2005.

Sanders GHW, Manz A. Chip-based microsystems for genomic and proteomic analysis. Trend Anal Chem. 19: 364-378, 2000.

Santini JT, Jr., Richards AC, Scheidt R, Cima MJ, Langer R. Microchips as controlled drug-delivery devices. Angw Chem Int Ed. 39: 2396-2407, 2000.

Schenk R, Hessel V, Hofmann C, Kiss J, Löwe H, Ziogas A. Numbering - up of microdevices: a first liquid-flow split unit. Chem Eng J. 101: 421-429, 2004.

Skelley AM, Kirak O, Suh H, Jaenisch R, Voldman J. Microfluidic control of cell pairing and fusion. Nat Methods. 6: 147-152, 2009.

Slyadnev MN, Lavrova MV, Erkin MA, Kazako VA, Geneev AA. Development of a multireactor microfluidic system for the determination of DNA using real time polymerase chain reaction. J Anal Chem. 63: 192-198, 2008.

Sobieszuk P, Cyganski P, Pohorecki R. Bubble lengths in the gas-liquid Taylor flow in microchannels. Chem Eng Res Des. 88: 263-269, 2010.

Sun Y, Liu Y, Qu W, Jiang X. Combining nanosurface chemistry and microfluidics for molecular analysis and cell biology. Anal Chim Acta. 650: 98-105, 2009.

Taff BM, Voldman J. A scalable addressable positive dielectrophoretic cell-sorting array. Anal Chem. 77: 7976-7983, 2005. 
Tanaka Y, Sato K, Yamato M, Okano T, Kitamori T. Cell culture and life support system for microbioreactor and bioassay. J Chromatogr A. 1111: 233-237, 2006.

Tas NR, Berenschot JW, Lammerink TSJ, Elwenspoek M, van der Berg A. Nanofluidic bubble pump using surface tension directed gas injection. Anal Chem. 74: 2224-2227, 2002.

Thery M, Bornens M. Cell shape and cell division. Curr Opin Cell Biol. 18: 648-657, 2006.

Tresset G, Takeuchi S. A microfluidic device for electrofusion of biological vesicles. Biomed Microdevices. 6: 213-218, 2004.

Urban PL, Goodall DM, Bruce NC. Enzymatic microreactors in chemical analysis and kinetic studies. Biotechnol Adv. 24: 42-57, 2006.

Valero A, Post JN, van Nieuwkasteele JW, Ter Braak PM, Kruijer W, van der Berg A. Gene transfer and protein dynamics in stem cells using single cells electroporation in a microfluidic device. Lab Chip. 8: 62-67, 2008.

Vecchio G, Sabella S, Tagliaferro L, Menegazzi P, Di Bello MP, Brunetti V, Cingolani R, Rinaldi R, Pompa PP. Modular plastic chio for one-shot human papillomavirus diagnostic analysis. Anal Biochem. 397: 53-59, 2010.

Waconge B, Pieralli, C, Roux C, Gharbi T. Measuring the mechanical behaviour of human oocytes with a very simple SU-8 micro-tool. Biomed Microdevices. 10: 411-419, 2008.

Walker GM, Zeringue HC, Beebe DJ. Microenvironment design considerations for cellular scale studies. Lab Chip. 4: 91-97, 2004.
Wang YM, Tegenfeldt JO, Reisner W, Riehn R, Guan XJ, Guo L, Golding I, Cox EC, Sturm J Austin RH. Single-molecule studies of repressor-DNA interactions show long-range interactions Proc Natl Acad Sci USA. 102: 9796-9801, 2005.

Watts P, Haswell SJ. Continuous flow reactors for drug discovery. Drug Discov Today. 8: 586-593, 2003.

Westermann T. Flow-trough membrane microreactor for intensified heterogeneous catalysis. PhD. Technisches Hochshule, Aachen 2009.

Wlodkowic D, Cooper JM. Tumours on chips: oncology meets microfluidics. Curr Opin Chem Biol. 14: 556-567, 2010.

Xiang Q, Hu G, Gao Y, Li D. Miniaturized immunoassay microfluidic system with electrokinetic control. Biosens Bioelectron. 21: 2006-2009, 2006.

Yi C, Li C-W, Ji S, Yang M. Microfluidics technology for manipulation and analysis of biological cells. Anal Chim Acta. 560: 1-23, 2006.

Zguris JC, Itle LJ, Hayes D, Pishko MV. Microreactor microfluidic systems with human microsomes and hepatocytes for use in metabolite studies. Biomed Microdevices. 7: 117-125, 2005.

Zhang $\mathrm{C}$, Jinliang X, Ma W, Zheng W. PCR microfluidic devices for DNA amplification. Biotechnol Adv. 24: 234-284, 2006.

Zhang Y, Ozdemir P. Microfluidic DNA amplification. Anal Chim Acta. 638: 115-125, 2009. 